\title{
A Proposed Paradigm for the Requirements for Designing and Using Digital Games-Based Learning by Educable Intellectual Disabled Children
}

\author{
Magda Saleh \\ Faculty of Early Childhood Education, Alexandria University, Egypt \\ magda.mahmoud@alexe.edu.eg \\ Marwa Battisha \\ Faculty of Early Childhood Education, Damanhour University, Egypt \\ marwa.battisha1@gmail.com
}

\begin{abstract}
This study aims to shed further light on how to utilize digital games in education as a contribution to developing educable intellectual disabled children's teaching and learning practices via identifying the requirements for their design and use at those children's classes. Notably, the researchers focused on using digital games in promoting educable intellectual disabled children's learning experiences highlighting their different practical mechanisms and teaching practices based on literature review. Also, types of digital games capable of fulfilling the teaching requirements of those children were identified by making a list of the requirements for designing and using digital games-based learning at educable intellectual disabled children's classes consisting of 38 various requirements divided into 3 major dimensions, namely: (1) educational requirements for using digital games-based learning; (2) instructional design requirements for using digital games-based learning; and (3) practical application requirements for using digital games-based learning. Then, the proposed list was applied to a sample consisting of 25 faculty members at 5 Egyptian universities. Following data statistical analysis, it was revealed that the questionnaire total mean score is 2.73 with a relative weight of $90.1 \%$. In a nutshell, such values verify that the questionnaire all proposed requirements are, indeed, very important for using digital games-based learning at educable intellectual disabled children's classes.
\end{abstract}

Keywords. Digital Games, Educable Intellectual Disabled Children, Instructional Design

\section{Introduction}

As a rule of thumb, intellectual disabled children's ability lack is considered an incentive and, at the same time, a challenge for conducting a plethora of research studies and conferences highlighting how to promote their limited psychological, educational, emotional, personal, linguistic 
and academic development in order to empower them to become good citizens in a society caring for their interests, fulfilling their needs and developing their abilities.

According to American Association on Intellectual and Developmental Disabilities ${ }^{1}$, educable intellectual disabled children (who obtain only 50-70 scores at IQ tests) have the potential to benefit from learning basic skills, e.g. literacy and numeracy, good adaptability after finishing their special education schools or classes as well as self-sufficiency enabling them to live independently and have a job in the future.

Basically, the term "Intellectual Disability" (ID) is used in educational literature to refer to a specific group of children and adults who suffer from specific shortcomings in their intellectual development, communication ability and weak social skills. As a result, the emergence of such deficiencies leads to a significant slower development and learning rates, compared to their other normal peers. Besides, they may spend more time learning speaking, walking, self-caring and fulfilling their different personal needs (Fisch, 2005).

Furthermore, technology allows special needs children to express their ideas thanks to its numerous psychological, academic, social or economic benefits as it provides them with advanced software with several amusing programs and educational games that bring joy to those young learners; thus relieving their stress and anxiety side by side with increasing their motivation to learn and to acquire new behaviors such as:

1- Literacy and Numeracy Skills: They usually oral and written linguistic skills representing the basic fields of using digital games at intellectual disabled children's curricula and instructional activities according to British Educational Communications and Technology Agency's (BECTA, 2008) taxonomy including numeracy skills, logical thinking, counting things, realizing the importance of time, etc.;

2- Social and Communication Skills: They provide intellectual disabled children with various programs for mastering required life skills for developing their basic functional skills for acquiring vocabulary and interaction with others in community and surrounding environment, financial management skills, shopping and the proper social behavior;

3- Personal Safety and Hygiene: They are closely related to designing suitable games for supporting intellectual disabled children's acquisition of health and life sciences using animations, graphics in a way allowing those children to deeply investigate different organs of the human body and health education topics as well as answer the frequently asked questions about human body;

4- Physical and Psychological Health: They provide children with games indicating their stress and anxiety, including their strengths and weaknesses and depression tendencies; and

5- Vocational Training (Selected Topics): It employs some certain games (e.g. cooking game) for increasing children's awareness of the daily tasks and responsibilities assigned to workers of 
different jobs, shaping a better understanding for responsibility-shouldering concepts, carrying out requested tasks and duties as well as job discipline.

\section{Study Goal:}

This study aims to identify the requirements for using digital games-based learning at educable intellectual disabled children's classes.

\section{Literature Review:}

American Psychiatric Association ${ }^{2}$ published the first edition of its famous book entitled "Diagnostic and Statistical Manual of Mental Disorders" in 1994 classifying intellectual disability cases into four basic levels according to IQ test scores and application results, namely:

1- Mild Disability: It applies to those children who obtain 50-70 scores (i.e. the disability category focus of the current study);

2- Moderate Disability: It applies to those children who obtain between 35-40 and 50-55 scores;

3- Severe Disability: It applies to those children who obtain between 20-25 and 35-40 scores; and

4- Profound Disability: It applies those children who obtain only 20-25 scores.

Sherlock et al (2005) provided a significant operational definition of the term "Intellectual Disability" (ID) as a special education category characterized by shortcomings in either functional intellectual performance or adaptive behavior as usually expressed by weak conceptual, social and practical adaptation skills.

Based on the above-mentioned definition, it's noticeable that weak adaptability to daily life situations is widely considered as a basic feature of intellectual disability various categories. Those individuals may suffer delayed development or lack of the so-called adaptive behavior skills, i.e. literacy, writing, receptive and expressive linguistic skills, financial concepts, self-direction, responsibility, self-efficacy, spontaneous behavior, understanding and following normative rules, carrying out daily life activities and employment skills necessary for joining labor market.

In light of the various technology tools provided to those children for promoting their excitement and motivation to express ideas, it is obvious there's, indeed, an urgent need to equip them with suitable opportunities to enjoy and feel self-satisfaction while participating in the educational process. Also, it's important to provide such children with the ability to benefit from the using digital games in formal learning processes at personal level empowering them to feel joy and excitement.

It's against such backdrop that it is significantly important to benefit from using digital gamesbased learning applications as effective instructional tools at intellectual disabled children's classes from an advanced integrated educational perspective; i.e. the main focus of the current study. 


\section{* Using Digital Games in Designing Intellectual Disabled Children's Learning Activities:}

Generally speaking, the terms "Computer Games", "Video Games", "Electronic Games", "Online Games" and "Digital Games' are usually used synonymously to refer to approximately the same thing.

All in all, Ke (2009) defines digital games as all types and formats of computer, video and online electronic games whereas Chen \& Wang (2009) define them as an effective instructional tool for enabling learners to construct knowledge via games, reach high levels of learning motivation and apply the acquired knowledge in solving realistic problems from their daily life.

Becker (2005) provided us with list of the main learning theories that largely correspond to digital games design principles, e.g. Five Categories of Learning and nine events of instruction theories and multiple Intelligences theory).

Becker (2005) adds that designing instructional and leisure digital dames used in education may much benefit from the support of a variety of different learning styles as exemplified by the possibility of benefiting from and he presented a prominent example represented in benefitting from the different learning levels emphasized by Gagné et al's (1992) instructional design model, such as learning the following aspects, namely:

- Verbal Information: Presenting digital games for children using both phonetic and textual formats;

- Intellectual Skills: Children's benefitting from learning the required concepts and problem solving rules like the majority of currently used digital games;

- Cognitive Strategies: They are fundamental and indispensable aspects for enabling the players to carry out digital games required tasks;

- Affective Attitudes: They are usually very important for role-playing digital games; and

- Motor Skills: They can be developed through digital game tools, i.e. certain control devices, joysticks or touch screens.

Tsai et al (2012) identified three main factors of the effectiveness of using digital games in education, directly or indirectly, contributing to promoting children's knowledge acquisition levels, namely: (see Figure 1)

1- Prior Knowledge which positively affects children's learning ability to successfully play the game;

2- Playing Motivation which includes children's learning motivation to seriously play the game;

3- Online Game Experience which includes children's playing skills to successfully complete the game. 
Figure 1: Factors of Effectiveness of Using Digital Games in Education

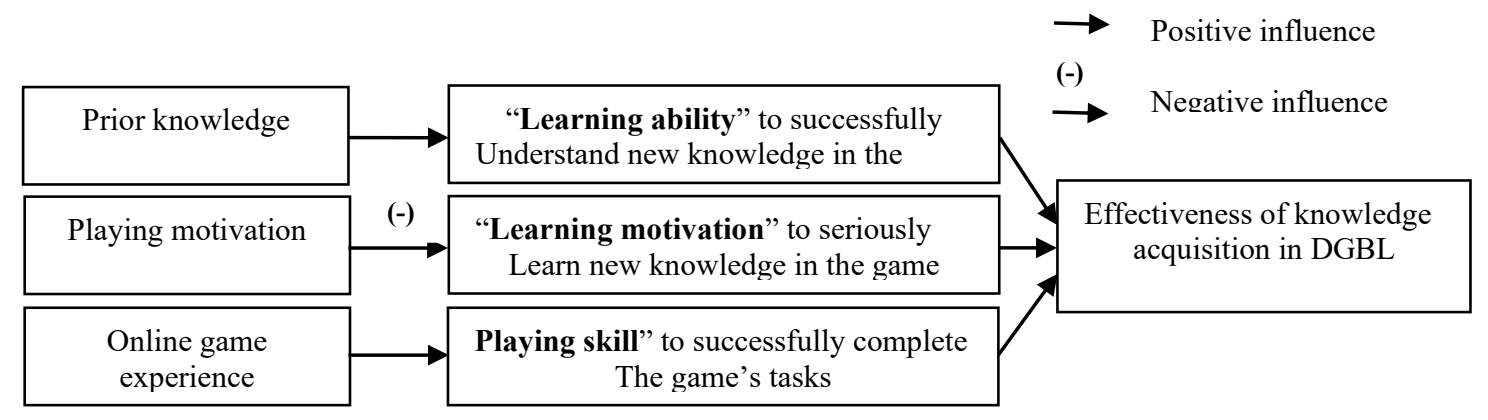

(Source: Tsai et al., 2012)

* Correlation between Intellectual Disabled Children's Teaching Requirements and Digital

\section{Gaming Capabilities:}

Based on literature review (e.g. Kalantzis, 1985; Brooks, 1997; Rooms, 2000; Christakis, 2002; Raybourn \& Waern, 2004; Lester, 2006; Saridaki et al., 2009), the researchers shed further light on the close association of intellectual disabled children's teaching requirements, digital gaming capabilities and digital game types from educational perspective in the following six main points:

1- Monitoring and Immediacy: Digital games enjoy advanced capabilities enabling them not only to monitor and follow players' behaviors but they also have the ability to offer them help when encountering hard situations besides providing hints for solving required problems, clarifying used steps, e.g. adventure, simulation and role-playing games;

2- Entrenchment and Practices: The majority of digital games rely on trial and error, repeating the used steps with the aim of enabling players to learn the required basic skills and continue playing via mastering advanced skills that contribute to realizing previously formulated educational goals;

3- Therapeutic Intervention and Assistance: This principle contributes to guaranteeing children' skills sustainability, correspondence with their prior backgrounds and assisting them to positively interact with others; thus helping them to relax when using simple leisure as well as drill and practice games accompanied by relaxing music and graphics;

4- Child-Centered/Individual Adaptation and Adaptive Curriculum: Digital games can focus on fulfilling one or more instructional requirements so that they are specialized as well as closely related to players' mental and chronological age in addition to their different interests and needs;

5- Curriculum Localization in the Direct Natural and Cultural Environment: Digital games are interactive in nature employing a narrative cinematic format contributing to an increase in their 
usage opportunities as an effective tool to teach desired affective attitudes and social behaviors in tandem with the child's surrounding cultural environment; and

6- Proximity to Real-Life Situations: Most digital games focus on simulating real-life situations in a way allowing players to easily live such situations, offering suitable solutions for their daily-life problems in addition to playing simulation games dealing with various daily activities, e.g. borrowing money, shopping, wearing elegant dresses, etc., thus enabling them to move closer to real-life situations.

More specifically, ${ }^{30}$ proposed a detailed list of the developmental requirements that must be fulfilled by the effective instructional design of digital games used in children's education classified into three main categories as follows:

\section{1-Cognitive Considerations, including:}

- Use of simple user interfaces for digital games containing very few, if any, written texts;

- Being careful on using visual symbols as they require further explanations and interpretations that may differ from one culture to another;

- Emphasis on the pivotal role played by parents in children's game-play;

- Encouraging children to use language in discussing the different problems they face while playing;

- Avoiding assigning children very complex tasks so that they don't return back again to rely on using the simpler initial thinking strategies that don't help them to master the required higherorder thinking skills; and

- Taking into consideration children's various development speed that is usually affected by biological factors, dominant cultures and experience.

\section{2-Socio-Emotional Considerations, including:}

- Taking into consideration the possible negative effect of children's egocentrism during such early development stage which weakness their ability to understand other alternative opinions and viewpoints other than their own;

- Children's egocentrism may cause their introversion and refusal of engagement with others;

- Young children may be less interested to use competition tools to stimulate their learning motivation; and

- 2-4 year-old children may perform irregular behaviors contrary to their 3-5 year-old peers who often carry out stable regular behaviors.

3-Psycho-Motor Considerations, including: 
- Taking into consideration motor skill development levels, eye-hand coordination when designing suitable digital game user interfaces for children;

- Taking into consideration the fact that children's eyes are not, in general, ready for gazing for relatively long periods of time;

- Similarity of male and female children's physical structure without noticeable differences; and

- Quick development of perceptual-motor abilities so that children usually suffer from spatialtemporal awareness disorders and unconsciousness of directions.

In addition, Bredekamp \& Copple ${ }^{9}$ provided us with other additional considerations which must be taken into account when designing digital games suitable for use in children's education, including:

- Pre-assumption that children are not able to read so that they would necessarily need older adults' help for reading any delivered written texts;

- Highlighting and clarifying the desired goals of designed games in a visually suitable format for children;

- Endeavoring, as possible, to avoid using too much navigation arrows and hyperlinks by the designed game. If used, it is advisable to employ horizontal arrows as they are usually deemed more intuitive and spontaneous for children;

- Placing the designed game active icons on suitable places on the screen;

- Employing user interfaces containing backgrounds, colors and graphics suitable for children so that they don't cause them cognitive overload;

- Use of 3D graphics, tactile stimuli in tandem with those children's motor skill development levels; and

- Mixing audio and visual instructions together in a way contributing to the achievement of the maximum possible effect on children.

\section{Types of Digital Games Suitable for Use in Teaching Intellectual Disabled Children:}

The most important types of digital games suitable for use in teaching intellectual disabled children can be summarized as follows:

1- Drill and Practice Games: Digital games traditionally used for instructional purposes are usually designed according to the drill and practice game design models. Thus, they include problems or multiple-choice questions related to specific topic arousing intellectual disabled children's interest. As a result, they generally focus on achieving a number of simple goals in addition to offering players multiple drill and practice activities at a certain course or discipline;

2- Adventure Games: They focus on participants' choice of playing the roles of certain characters via collecting required information as well as benefitting from its practical use them in solving 
problems or dealing with required situations at the same time they enjoy high level of joy and excitement;

3- Simulation Games: They enable educable intellectual disabled children/ players to learn how to deal with multiple variables determining the final results and outcomes of a certain situation. Also, they enable players, in general, to have some control on managing certain things simulated from real life (e.g. supermarkets, amusement parks, etc.); and

4- Role-Playing Games (RGPGs): They often provide intellectual disabled players with the opportunity for engaging in complete interaction with all the situations and problems they encounter during play. Besides, such digital games rely on rich historical heritage of storytelling through benefitting from employing new and innovative approaches for digital storytelling.

\section{* Requirements for Using Digital Game Activities at Educable Intellectual Disabled Children's} Classes:

According to Hasselbring \& Glaser (2000), Bierre et al (2005), Saridaki et al (2009) and Hovious \& Van Eck (2015), the researchers summarized the most pivotal requirements for using digital games at educable intellectual disabled children's classes as follows:

- Overcoming accessibility problems as they don't enable all those children to use digital games and benefit from them in the learning process on equal footing with their other peers;

- Taking into consideration the narrative styles used by digital game narrative texts so that those children are provided with onscreen subtitles as well as suitable level of guidance and technical support, whether by teachers or game designers;

- Taking into consideration intellectual disabled children's ability to carry out digital games assigned tasks. Therefore, their potentials and capabilities must be taken into account side by side with simplifying their understanding of the used games desired goals, easing game actions and providing its instructions in simple textual or visual formats. Also, audio may be used to take into account the needs of those children/players who suffer from reading difficulties or problems due to using written texts that are often unsuitable to their mental abilities;

- Adjusting used digital games speed to adapt to children's cognitive and recalling abilities while learning. Therefore, their technical problems related to used games which don't match their own capabilities must be taken into consideration (e.g. participating in digital games requiring players to commit themselves to a pre-determined timing);

- Observing children's performance during play as they may achieve digital games desired goals. However, they mayn't realize their educational value because they only focus on their use as leisure/recreational tools without a similar focus on highlighting their educational value; 
- Training special education teachers on the technical issues related to using, operating and maintaining the digital games used in educating intellectual disabled children;

- Paying more attention to available logistical infrastructure and facilities in order to maximize special education teachers' benefits from employing advanced digital games in promoting educable intellectual disabled children's teaching and learning practices for several reasons, most prominently poor budget as well as financial allocations and resources available on the ground;

- Designing user interfaces with high intuition levels for those children;

- Digital game interface symbols, lines, visual stimuli and commonly used components must be familiar to children;

- Reducing the time periods allocated for operating and using digital games due to those children' short and limited attention span;

- Preparing good educational design for the educational goals and implications of the games delivered to intellectual disabled children so that they don't negatively affect them and lead to their acquisition of some negative behaviors as digital games are, indeed, as a fundamental important dimension of young children's lives at the same time it's seen as a double-edged weapon having both advantages and disadvantages (Nolan \& McBride, 2014);

- Support the interactivity and feedback of digital games delivered to disabled children (Renkl \& Atkinson 2007; Ritterfeld et al., 2009; Liao et al., 2011) because of their close correlation with the available opportunities for players to give and receive feedback on their different actions and behaviors which affect followed digital game paths (Renkl \& Atkinson, 2007; Ritterfeld et al., 2009); and

- Taking into consideration control ability level (Qin et al., 2009) due to its correlation to players' ability to manage their control when playing digital games (e.g. using control mechanisms or storytelling flow). Kalantzis (1985) emphasizes the importance of being careful when using storytelling-based interactive digital games with educable intellectual disabled children so that simulation and role-playing games don't cause them to feel stressed and restless resulting from their non-understandable scenarios, graphics, audio effects or complex adventures for those children;

- Providing the opportunity for identity formulation as it is important to provide players with suitable opportunities to make relationships and connections with digital game other characters or transform them, themselves, to become characters of those same games via using virtual reality (Bloscovich \& Bailensen, 2011); and

- Providing participation and immersion-supporting tools so that players feel present and immersed while playing and using digital games (Tamborini \& Skalski, 2006). 


\section{Statement of the Problem:}

Results of many previous studies verified the effectiveness of using digital games, especially virtual reality-based computer games, with special needs and intellectual disabled children in teaching fire safety skills, improving communications skills and promoting those children learning levels (Vera et al., 2005; Padgett \& Strickland, 2006; Marco et al., 2012; Chuang et al., 2010).

For example, Williams et al (2001) revealed the effectiveness of using digital games, especially multimedia games, in developing reading skills and learning required concepts among a selected sample of autistic children whereas Griffiths (2002) also proved the effectiveness of using digital games, especially video games, in developing basic linguistic, sport and social skills necessary for children with special needs.

It's against such backdrop that it is clear that there's a consensus among educational researchers on the tremendous importance of digital games as effective instructional tools for intellectual disabled children. However, the instructional design of digital game software delivered to those children in Egypt and other Arab Countries suffers from several obstacles and needs particular considerations for the design and production processes of those games according to their needs and intellectual disability multiple levels. As a result, there's an urgent need to formulate suitable standards and evidences for designing e-learning content tools delivered to those children, i.e. the main focus of the current study.

More specifically, in order to properly address such research problem, the current study aims to answer the following main question: "What are the requirements for using digital games-based

\section{learning at educable intellectual disabled children's classes?".}

This main question is then sub-branched into the following three sub-questions, namely:

1- What are the educational requirements for using digital games-based learning at educable intellectual disabled children's classes?;

2- What are the instructional design requirements for using digital games-based learning at educable intellectual disabled children's classes?; and

3- What are the practical application requirements for using digital games-based learning at educable intellectual disabled children's classes?.

\section{Methods:}

This study used the descriptive-analytical method in preparing the proposed list of the perquisite requirements for designing and using digital games-based learning at educable intellectual disabled children's classes.

\section{* Study Sample:}


The study sample consisted of 25 faculty members at 5 Egyptian universities affiliated to multiple disciplines, i.e. special education, early childhood and educational technology.

\section{5-Instruments:}

They included the proposed list of the perquisite requirements for designing and using digital games-based learning at educable intellectual disabled children's classes in light of which a questionnaire was prepared containing this list various dimensions based on literature review and above-mentioned studies for formulating its initial form containing 40 requirements.

\section{6-Procedure:}

\section{I-Questionnaire Validity:}

It has been verified using two methods, namely:

1- Referee Validity in order to benefit from expert peer-referees' opinions, amendments or revisions. As a result, following receiving such amendments, the questionnaire final form contained 38 requirements.

2- Internal Consistency Validity: It was verified by applying the questionnaire on a pilot sample consisting of 15 subjects other than the research core sample participants. Notably, Spearman's Rank Correlation Coefficient was used to calculate item-dimension and dimension-total correlation coefficients.

As a consequence, the following results were concluded: 


\section{(10) TECHNIUM}

Table (1):

Results of Calculating Internal Consistency

Validity for Questionnaire Items $(N=15)$

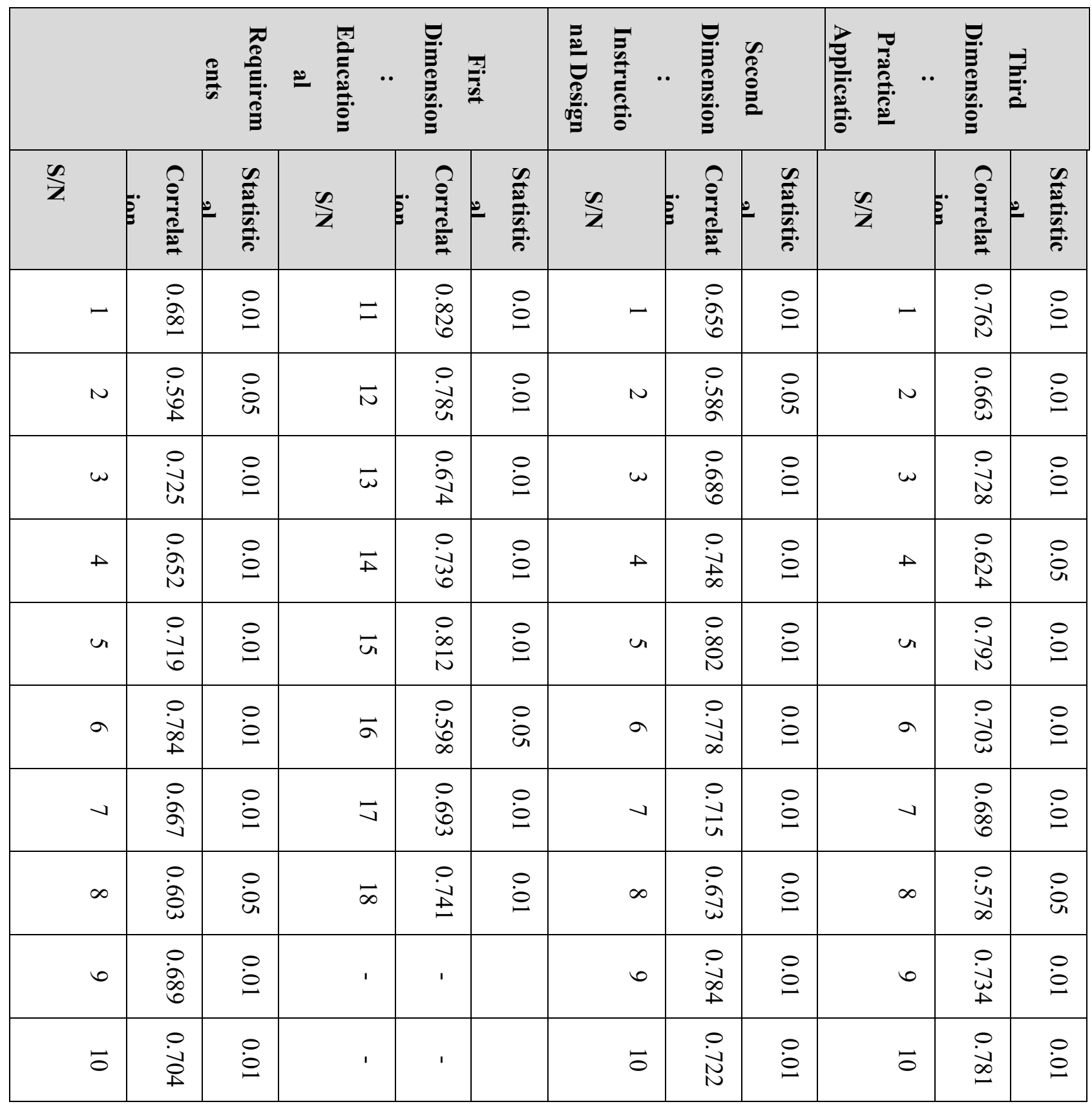

Table (1) shows that all item-dimension correlation coefficients are statistically significant at both 0.01 and 0.05 levels; thus providing us with a strong empirical evidence emphasizing that all questionnaire items already enjoy high satisfactory levels of internal consistency validity from psychometric perspective. 
Table (2):

Results of Calculating Total Internal Consistency

Validity for Questionnaire Dimensions $(N=15)$

\begin{tabular}{|c|c|c|}
\hline Questionnaire Dimensions & $\begin{array}{c}\text { Correlation } \\
\text { Coefficient }\end{array}$ & $\begin{array}{c}\text { Statistical } \\
\text { Significance }\end{array}$ \\
\hline $\begin{array}{c}\text { First Dimension: } \\
\text { Educational Requirements }\end{array}$ & 0.843 & $\mathrm{P}<0.01$ \\
\hline $\begin{array}{c}\text { Second Dimension: Instructional } \\
\text { Design Requirements }\end{array}$ & 0.679 & $\mathrm{P}<0.01$ \\
\hline $\begin{array}{c}\text { Third Dimension: } \\
\text { Practical Application } \\
\text { Requirements }\end{array}$ & 0.728 & $\mathrm{P}<0.01$ \\
\hline
\end{tabular}

Table (2) shows that values of all dimension-total correlation coefficients are statistically significant at the 0.01 level; thus providing us with a strong empirical evidence emphasizing that all questionnaire dimensions already enjoy high satisfactory levels of internal consistency validity from psychometric perspective.

\section{Questionnaire Reliability:}

It has been verified using two methods, namely:

\section{1-Calculating Questionnaire Reliability Using the Cronbach's Alpha Method:}

Cronbach's Alpha $(\alpha)$ Method was used to calculate the reliability of the questionnaire dimensions and its total score employing the "Statistical Package for the Social Sciences" (SPSS) software package as a tool for analyzing the data collected by the researchers from their pilot sample; thus concluding the following results: 
Table (3):

Results of Calculating Questionnaire Reliability

Using the Cronbach's Alpha Method ( $N=15)$

\begin{tabular}{|c|c|c|}
\hline $\begin{array}{c}\text { Questionnaire } \\
\text { Dimensions }\end{array}$ & $\begin{array}{c}\text { No of } \\
\text { Items }\end{array}$ & $\begin{array}{c}\text { Reliability } \\
\text { Coefficient }\end{array}$ \\
\hline $\begin{array}{c}\text { First Dimension: } \\
\text { Educational Requirements }\end{array}$ & 18 & 0.854 \\
\hline $\begin{array}{c}\text { Second Dimension: Instructional } \\
\text { Design Requirements }\end{array}$ & 10 & 0.783 \\
\hline $\begin{array}{c}\text { Third Dimension: } \\
\text { Practical Application } \\
\text { Requirements }\end{array}$ & 10 & 0.819 \\
\hline First Dimension: & 38 & 0.872 \\
\hline Educational Requirements & & \\
\hline
\end{tabular}

Table (3) shows that all questionnaire dimensions have high statistically significant reliability coefficients when using the Cronbach's Alpha Method; thus providing us with a strong empirical evidence emphasizing they already enjoy high satisfactory levels of reliability from psychometric perspective.

\section{2-Calculating Questionnaire Reliability Using the Split-Half Method:}

The questionnaire items were split into two halves: single vs. double items. Spearman's Rank Correlation Coefficient was used to calculate the correlation between its first and second halves. Then, the questionnaire length was amended using Spearman-Brown Prediction Formula; thus concluding the following results: 
Table (4):

Results of Calculating Questionnaire Reliability

Using the Split-Half Method $(N=15)$

\begin{tabular}{|c|c|c|}
\hline $\begin{array}{c}\text { Questionnaire } \\
\text { Dimensions }\end{array}$ & $\begin{array}{c}\text { Correlation } \\
\text { Coefficient }\end{array}$ & $\begin{array}{c}\text { Reliability } \\
\text { Coefficient }\end{array}$ \\
\hline $\begin{array}{c}\text { First Dimension: } \\
\text { Educational Requirements }\end{array}$ & 0.732 & 0.845 \\
\hline $\begin{array}{c}\text { Second Dimension: Instructional } \\
\text { Design Requirements }\end{array}$ & 0.681 & 0.811 \\
\hline $\begin{array}{c}\text { Third Dimension: } \\
\text { Practical Application } \\
\text { Requirements }\end{array}$ & 0.705 & 0.827 \\
\hline First Dimension: & & 0.858 \\
\hline Educational Requirements & & \\
\hline
\end{tabular}

Table (4) shows that all questionnaire dimensions have high statistically significant reliability coefficients when using the Split-Half Method; thus providing us with a strong empirical evidence emphasizing they already enjoy high satisfactory levels of reliability from psychometric perspective and that the entire questionnaire can be used as a data collecting tool in the current study.

\section{7-Results:}

In order to answer their study questions, the researchers applied the survey questionnaire including the proposed list of the perquisite requirements for designing and using digital games-based learning at educable intellectual disabled children's classes to a sample consisting of 25 faculty members at 5 Egyptian universities. Then, they statistically analyzed collected data using 3-Point Likert Scale to determine the response degree as follows: 3 = Very Important Response; 2 = Important Response; and 1 = Not Important Response. Accordingly, the following standard was used to judge results mean score values (Walpole, 1998):

- If the mean score varies from 1 to 1.67 , it's considered highly important;

- If the mean score varies from more than 1.67 to 2.34 , it's considered of a medium importance degree; and

- If the mean score varies from more than 2.34 to 3.00, it's considered of a low importance degree. 
Notably, the study statistical treatments were carried out using the IBM ${ }^{\circledR}$ SPSS ${ }^{\circledR}$ Statistics 24 . Following field application of the study instruments, data statistical analysis as well as results discussion and interpretation (in light of the study previously mentioned theoretical framework and related literature review), the researchers would highlight their concluded results relevant to answering the study questions as follows:

\section{* Answering the First Question:}

The first question states "What are the educational requirements for using digital games-based learning at educable intellectual disabled children's classes?"

To answer such question, the researchers calculated the frequencies, percentages, mean scores and relative weights of the sample participants' responses to the questionnaire first dimension items that were then arranged in descending order in light of their ranks; thus concluding the following results:

\section{Table (5):}

Sample Participants' Responses for Identifying the Educational Requirements for Using Digital

Games-Based Learning at Educable Intellectual Disabled Children's Classes $(N=25)$

\begin{tabular}{|c|c|c|c|c|c|c|c|c|c|c|}
\hline \multirow[b]{2}{*}{$\mathbf{S} / \mathbf{N}$} & \multirow{2}{*}{$\begin{array}{c}\text { Frequenc } \\
\text { ies \& } \\
\text { Percenta } \\
\text { ges }\end{array}$} & \multirow[b]{2}{*}{ Items } & \multicolumn{3}{|c|}{ Response Degree } & \multirow{2}{*}{$\begin{array}{l}\text { Me } \\
\text { an } \\
\text { Sco } \\
\text { re }\end{array}$} & \multirow{2}{*}{$\begin{array}{c}\text { Stand } \\
\text { ard } \\
\text { Deviat } \\
\text { ion }\end{array}$} & \multirow{2}{*}{$\begin{array}{c}\text { Relati } \\
\text { ve } \\
\text { Weigh } \\
\text { t }\end{array}$} & \multirow{2}{*}{$\begin{array}{c}\text { Impor } \\
\text { tance } \\
\text { Degre } \\
\text { e }\end{array}$} & \multirow[b]{2}{*}{$\begin{array}{l}\text { Ra } \\
\text { nk }\end{array}$} \\
\hline & & & $\begin{array}{l}\text { Very } \\
\text { Import } \\
\text { ant }\end{array}$ & $\begin{array}{l}\text { Impo } \\
\text { rtant }\end{array}$ & $\begin{array}{l}\text { Not } \\
\text { Impo } \\
\text { rtant }\end{array}$ & & & & & \\
\hline \multirow{2}{*}{1} & $\begin{array}{l}\text { Frequenci } \\
\text { es }\end{array}$ & $\begin{array}{l}\text { Digital games fulfill } \\
\text { intellectual disabled }\end{array}$ & 23 & 2 & 0 & \multirow{2}{*}{$\begin{array}{c}2.9 \\
2\end{array}$} & \multirow{2}{*}{0.28} & \multirow{2}{*}{$96.4 \%$} & \multirow{2}{*}{ High } & \multirow{2}{*}{3} \\
\hline & $\begin{array}{c}\text { Percentag } \\
\text { es }\end{array}$ & $\begin{array}{c}\text { children's } \\
\text { developmental needs. }\end{array}$ & 92.0 & 8.0 & 0.0 & & & & & \\
\hline \multirow{2}{*}{2} & $\begin{array}{l}\text { Frequenci } \\
\text { es }\end{array}$ & $\begin{array}{l}\text { Formulating digital } \\
\text { game desired goals in }\end{array}$ & 25 & 0 & 0 & \multirow{2}{*}{$\begin{array}{c}3.0 \\
0\end{array}$} & \multirow{2}{*}{0.00} & \multirow{2}{*}{$\begin{array}{c}100.0 \\
\%\end{array}$} & & \multirow{2}{*}{1} \\
\hline & $\begin{array}{l}\text { Percentag } \\
\text { es }\end{array}$ & $\begin{array}{l}\text { tandem with intellectual } \\
\text { disability levels. }\end{array}$ & 100.0 & 0.0 & 0.0 & & & & & \\
\hline \multirow[b]{2}{*}{3} & $\begin{array}{l}\text { Frequenci } \\
\text { es }\end{array}$ & $\begin{array}{l}\text { Identifying entry levels } \\
\text { or describing intellectual }\end{array}$ & 24 & 1 & 0 & \multirow{2}{*}{$\begin{array}{c}2.6 \\
9\end{array}$} & \multirow[b]{2}{*}{0.20} & \multirow[b]{2}{*}{$97.7 \%$} & \multirow[b]{2}{*}{ High } & \multirow[b]{2}{*}{2} \\
\hline & $\begin{array}{c}\text { Percentag } \\
\text { es }\end{array}$ & $\begin{array}{l}\text { disabled children's } \\
\text { perquisite requirements } \\
\text { for using digital games. }\end{array}$ & 96.0 & 4.0 & 0.0 & & & & & \\
\hline 4 & Frequenci & Clarity of digital game & 20 & 4 & 1 & 2.6 & 0.52 & $91.1 \%$ & High & 7 \\
\hline
\end{tabular}




\begin{tabular}{|c|c|c|c|c|c|c|c|c|c|c|}
\hline & es & \multirow[t]{2}{*}{ ideas logical sequence. } & & & & \multirow[t]{2}{*}{7} & & & & \\
\hline & $\begin{array}{c}\text { Percentag } \\
\text { es }\end{array}$ & & 80.0 & 16.0 & 4.0 & & & & & \\
\hline \multirow[b]{2}{*}{5} & $\begin{array}{c}\text { Frequenci } \\
\text { es }\end{array}$ & \multirow{2}{*}{$\begin{array}{l}\text { Designing digital game } \\
\text { ideas and tasks in } \\
\text { tandem with intellectual } \\
\text { disabled children's } \\
\text { capabilities and } \\
\text { potentials. }\end{array}$} & 23 & 2 & 0 & \multirow[b]{2}{*}{$\begin{array}{l}2.8 \\
4\end{array}$} & \multirow[b]{2}{*}{0.55} & \multirow[b]{2}{*}{$93.7 \%$} & \multirow[b]{2}{*}{ High } & \multirow[b]{2}{*}{5} \\
\hline & $\begin{array}{c}\text { Percentag } \\
\text { es }\end{array}$ & & 92.0 & 8.0 & 0.0 & & & & & \\
\hline \multirow[b]{2}{*}{6} & $\begin{array}{c}\text { Frequenci } \\
\text { es }\end{array}$ & \multirow{2}{*}{$\begin{array}{l}\text { Good instructional } \\
\text { design for digital game } \\
\text { educational goals and } \\
\text { implications suitable for } \\
\text { intellectual disabled } \\
\text { children. }\end{array}$} & 18 & 5 & 2 & \multirow[b]{2}{*}{$\begin{array}{l}2.6 \\
4\end{array}$} & \multirow[b]{2}{*}{0.64} & \multirow[b]{2}{*}{$87.1 \%$} & \multirow[b]{2}{*}{ High } & \multirow[b]{2}{*}{12} \\
\hline & $\begin{array}{c}\text { Percentag } \\
\text { es }\end{array}$ & & 72.0 & 20.0 & 8.0 & & & & & \\
\hline \multirow{2}{*}{7} & $\begin{array}{c}\text { Frequenci } \\
\text { es }\end{array}$ & \multirow{2}{*}{$\begin{array}{l}\text { Designing real-world } \\
\text { problems for digital } \\
\text { games closely related to } \\
\text { daily life practices. }\end{array}$} & 18 & 7 & 0 & \multirow{2}{*}{$\begin{array}{c}2.7 \\
2\end{array}$} & \multirow{2}{*}{0.46} & \multirow{2}{*}{$89.8 \%$} & \multirow{2}{*}{ High } & \multirow{2}{*}{8} \\
\hline & $\begin{array}{c}\text { Percentag } \\
\text { es }\end{array}$ & & 72.0 & 28.0 & 0.0 & & & & & \\
\hline \multirow[b]{2}{*}{8} & $\begin{array}{c}\text { Frequenci } \\
\text { es }\end{array}$ & \multirow{2}{*}{$\begin{array}{l}\text { Providing intellectual } \\
\text { disabled children with } \\
\text { immediate feedback for } \\
\text { their different actions } \\
\text { and behaviors when } \\
\text { using digital games. }\end{array}$} & 22 & 3 & 0 & \multirow[b]{2}{*}{$\begin{array}{c}2.8 \\
8\end{array}$} & \multirow[b]{2}{*}{0.33} & \multirow[b]{2}{*}{$95.0 \%$} & \multirow[b]{2}{*}{ High } & \multirow[b]{2}{*}{4} \\
\hline & $\begin{array}{c}\text { Percentag } \\
\text { es }\end{array}$ & & 88.0 & 12.0 & 0.0 & & & & & \\
\hline \multirow[b]{2}{*}{9} & $\begin{array}{c}\text { Frequenci } \\
\text { es }\end{array}$ & \multirow{2}{*}{$\begin{array}{l}\text { Scaffolding intellectual } \\
\text { disabled children's right } \\
\text { responses so that they } \\
\text { are immediate and } \\
\text { suitable for such } \\
\text { children. }\end{array}$} & 16 & 6 & 3 & \multirow[b]{2}{*}{$\begin{array}{c}2.5 \\
2\end{array}$} & \multirow[b]{2}{*}{0.71} & \multirow[b]{2}{*}{$83.2 \%$} & \multirow[b]{2}{*}{ High } & \\
\hline & $\begin{array}{c}\text { Percentag } \\
\text { es }\end{array}$ & & 64.0 & 24.0 & 12.0 & & & & & 15 \\
\hline 10 & $\begin{array}{c}\text { Frequenci } \\
\text { es }\end{array}$ & $\begin{array}{l}\text { Skill progression from } \\
\text { simpler to more }\end{array}$ & 20 & 5 & 0 & 2.8 & 0.41 & $92.4 \%$ & High & 6 \\
\hline & Percentag & complex levels. & 80.0 & 20.0 & 0.0 & & & & & \\
\hline
\end{tabular}




\begin{tabular}{|c|c|c|c|c|c|c|c|c|c|c|}
\hline & es & & & & & & & & & \\
\hline \multirow[b]{2}{*}{11} & $\begin{array}{c}\text { Frequenci } \\
\text { es }\end{array}$ & \multirow{2}{*}{$\begin{array}{l}\text { Identifying adequate } \\
\text { number of possible } \\
\text { options for players } \\
\text { (taking into account } \\
\text { performance-choice } \\
\text { conditions and } \\
\text { requirements). }\end{array}$} & 19 & 4 & 2 & \multirow[b]{2}{*}{$\begin{array}{c}2.6 \\
8\end{array}$} & \multirow[b]{2}{*}{0.63} & \multirow[b]{2}{*}{$88.4 \%$} & \multirow[b]{2}{*}{ High } & \multirow[b]{2}{*}{11} \\
\hline & $\begin{array}{c}\text { Percentag } \\
\text { es }\end{array}$ & & 76.0 & 16.0 & 8.0 & & & & & \\
\hline \multirow{2}{*}{12} & $\begin{array}{c}\text { Frequenci } \\
\text { es }\end{array}$ & \multirow{2}{*}{$\begin{array}{l}\text { Providing incentives for } \\
\text { encouraging players to } \\
\text { make progress and move } \\
\text { to digital game higher } \\
\text { levels. }\end{array}$} & 16 & 8 & 1 & \multirow{2}{*}{$\begin{array}{c}2.6 \\
0\end{array}$} & \multirow{2}{*}{0.58} & \multirow{2}{*}{$85.8 \%$} & \multirow{2}{*}{ High } & \multirow{2}{*}{13} \\
\hline & $\begin{array}{c}\text { Percentag } \\
\text { es }\end{array}$ & & 64.0 & 32.0 & 4.0 & & & & & \\
\hline \multirow{2}{*}{13} & $\begin{array}{c}\text { Frequenci } \\
\text { es }\end{array}$ & \multirow{2}{*}{$\begin{array}{l}\text { Offering attraction, joy } \\
\text { and excitement at } \\
\text { produced digital games. }\end{array}$} & 15 & 7 & 3 & \multirow{2}{*}{$\begin{array}{c}2.4 \\
8\end{array}$} & \multirow{2}{*}{0.72} & \multirow{2}{*}{$81.8 \%$} & \multirow{2}{*}{ High } & \multirow{2}{*}{16} \\
\hline & $\begin{array}{c}\text { Percentag } \\
\text { es }\end{array}$ & & 60.0 & 28.0 & 12.0 & & & & & \\
\hline \multirow{2}{*}{14} & $\begin{array}{c}\text { Frequenci } \\
\text { es }\end{array}$ & \multirow{2}{*}{$\begin{array}{l}\text { Identifying digital game } \\
\text { patterns and control } \\
\text { levels for intellectual } \\
\text { disabled children. }\end{array}$} & 17 & 5 & 3 & \multirow{2}{*}{$\begin{array}{c}2.5 \\
6\end{array}$} & \multirow{2}{*}{0.71} & \multirow{2}{*}{$84.5 \%$} & \multirow{2}{*}{ High } & \multirow{2}{*}{14} \\
\hline & $\begin{array}{c}\text { Percentag } \\
\text { es }\end{array}$ & & 68.0 & 20.0 & 12.0 & & & & & \\
\hline \multirow{2}{*}{15} & $\begin{array}{c}\text { Frequenci } \\
\text { es }\end{array}$ & \multirow{2}{*}{$\begin{array}{l}\text { Digital games include } \\
\text { multiple easy and hard } \\
\text { levels suitable for } \\
\text { intellectual disability } \\
\text { levels. }\end{array}$} & 20 & 3 & 2 & \multirow{2}{*}{$\begin{array}{c}2.7 \\
2\end{array}$} & \multirow{2}{*}{0.61} & \multirow{2}{*}{$89.8 \%$} & \multirow{2}{*}{ High } & \multirow{2}{*}{9} \\
\hline & $\begin{array}{c}\text { Percentag } \\
\text { es }\end{array}$ & & 80.0 & 12.0 & 8.0 & & & & & \\
\hline \multirow[b]{2}{*}{16} & $\begin{array}{c}\text { Frequenci } \\
\text { es }\end{array}$ & \multirow{2}{*}{$\begin{array}{l}\text { Focus on providing a } \\
\text { "wholly integrated } \\
\text { image" for learning } \\
\text { topics (i.e. game } \\
\text { cognitive or } \\
\text { psychomotor aspects) } \\
\text { rather than focus on } \\
\text { their secondary ideas }\end{array}$} & 14 & 8 & 3 & & & & & \\
\hline & $\begin{array}{c}\text { Percentag } \\
\text { es }\end{array}$ & & 56.0 & 32.0 & 12.0 & $\begin{array}{c}2.4 \\
4\end{array}$ & 0.71 & $80.5 \%$ & High & 17 \\
\hline
\end{tabular}




\begin{tabular}{|c|c|c|c|c|c|c|c|c|c|c|}
\hline & & and details. & & & & & & & & \\
\hline \multirow[b]{2}{*}{17} & $\begin{array}{c}\text { Frequenci } \\
\text { es }\end{array}$ & \multirow{2}{*}{$\begin{array}{l}\text { Using analogies, } \\
\text { practical examples and } \\
\text { instructional scenarios } \\
\text { suitable for intellectual } \\
\text { disabled children. }\end{array}$} & 18 & 6 & 1 & \multirow{2}{*}{$\begin{array}{c}2.6 \\
8\end{array}$} & \multirow[b]{2}{*}{0.56} & \multirow[b]{2}{*}{$88.4 \%$} & \multirow[b]{2}{*}{ High } & \multirow[b]{2}{*}{10} \\
\hline & $\begin{array}{c}\text { Percentag } \\
\text { es }\end{array}$ & & 72.0 & 24.0 & 4.0 & & & & & \\
\hline \multirow{2}{*}{18} & $\begin{array}{c}\text { Frequenci } \\
\text { es }\end{array}$ & \multirow{2}{*}{$\begin{array}{l}\text { Providing opportunities } \\
\text { to develop sense of } \\
\text { belonging via } \\
\text { interaction with digital } \\
\text { game symbols. }\end{array}$} & 14 & 7 & 4 & \multirow{2}{*}{$\begin{array}{c}2.4 \\
0\end{array}$} & \multirow{2}{*}{0.76} & \multirow{2}{*}{$79.2 \%$} & \multirow{2}{*}{ High } & \multirow[b]{2}{*}{18} \\
\hline & $\begin{array}{c}\text { Percentag } \\
\text { es }\end{array}$ & & 56.0 & 28.0 & 16.0 & & & & & \\
\hline \multicolumn{6}{|c|}{ Total Mean Score } & $\begin{array}{c}2.7 \\
0\end{array}$ & 0.53 & $89.1 \%$ & & \\
\hline
\end{tabular}

As Table (5) illustrates, the questionnaire first dimension has a total mean score with a statistically significant value; thus emphasizing the fact that the educational requirements for using digital games-based learning at educable intellectual disabled children's classes have a high degree of importance. Notably, this result may be attributed to the significance of such educational requirements for designing digital games used in education as they are widely considered as their basic foundations.

\section{* Answering the Second Question:}

The second question states "What are the instructional design requirements for using digital games-based learning at educable intellectual disabled children's classes?"

To answer such question, the researchers calculated the frequencies, percentages, mean scores and relative weights of the sample participants' responses to the questionnaire second dimension items that were then arranged in descending order in light of their ranks; thus concluding the following results:

\section{Table (6):}

Sample Participants' Responses for Identifying the Instructional Design Requirements for Using Digital Games-Based Learning at Educable Intellectual Disabled Children's Classes $(N=25)$

\begin{tabular}{|c|c|c|c|c|c|c|c|c|c|c|}
\hline \multirow{3}{*}{ S/N } & Frequenc & ies \& & \multirow{2}{*}{ Items } & \multicolumn{2}{|c|}{ Response Degree } & Mea & Stand & Rela & Impor & Ran \\
\cline { 3 - 7 } & Percenta & & Very & Imp & Not & $\mathbf{n}$ & ard & tive & tance & Ran \\
& & & Impor & orta & impo & Scor & Deviat & Weig & Degre & $k$ \\
\hline
\end{tabular}




\begin{tabular}{|c|c|c|c|c|c|c|c|c|c|c|}
\hline & ges & & $\tan t$ & nt & rtant & e & ion & ht & e & \\
\hline \multirow[b]{2}{*}{1} & $\begin{array}{c}\text { Frequenci } \\
\text { es }\end{array}$ & \multirow{2}{*}{$\begin{array}{l}\text { Using high-quality and } \\
\text { familiar graphics, } \\
\text { diagrams and visual } \\
\text { stimuli to intellectual } \\
\text { disabled children. }\end{array}$} & 19 & 6 & 0 & \multirow[b]{2}{*}{2.76} & \multirow[b]{2}{*}{0.44} & \multirow{2}{*}{$\begin{array}{c}91.1 \\
\%\end{array}$} & \multirow[b]{2}{*}{ High } & \multirow[b]{2}{*}{7} \\
\hline & $\begin{array}{c}\text { Percentag } \\
\text { es }\end{array}$ & & 67.0 & 24.0 & 0.0 & & & & & \\
\hline \multirow{2}{*}{2} & Frequenci & \multirow{2}{*}{$\begin{array}{l}\text { Designing user } \\
\text { interfaces with high } \\
\text { levels of intuition. }\end{array}$} & 25 & 0 & 0 & \multirow{2}{*}{3.00} & \multirow{2}{*}{0.00} & \multirow{2}{*}{$\begin{array}{l}100 . \\
0 \%\end{array}$} & \multirow[b]{2}{*}{ High } & \multirow[b]{2}{*}{1} \\
\hline & $\begin{array}{c}\text { Percentag } \\
\text { es }\end{array}$ & & 100.0 & 0.0 & 0.0 & & & & & \\
\hline \multirow{2}{*}{3} & $\begin{array}{c}\text { Frequenci } \\
\text { es }\end{array}$ & \multirow{2}{*}{$\begin{array}{l}\text { Accessibility in tandem } \\
\text { with intellectual } \\
\text { disability levels. }\end{array}$} & 24 & 1 & 0 & \multirow{2}{*}{2.96} & \multirow{2}{*}{0.20} & \multirow{2}{*}{$\begin{array}{c}97.7 \\
\%\end{array}$} & \multirow{2}{*}{ High } & \multirow{2}{*}{2} \\
\hline & $\begin{array}{c}\text { Percentag } \\
\text { es }\end{array}$ & & 96.0 & 4.0 & 0.0 & & & & & \\
\hline \multirow[b]{2}{*}{4} & $\begin{array}{c}\text { Frequenci } \\
\text { es }\end{array}$ & \multirow{2}{*}{$\begin{array}{l}\text { Providing the verbal } \\
\text { instructions and } \\
\text { technical support during } \\
\text { various stages of } \\
\text { interaction with digital } \\
\text { games. }\end{array}$} & 23 & 2 & 0 & \multirow[b]{2}{*}{2.92} & \multirow[b]{2}{*}{0.28} & \multirow[b]{2}{*}{$\begin{array}{c}69.4 \\
\%\end{array}$} & \multirow[b]{2}{*}{ High } & \multirow[b]{2}{*}{3} \\
\hline & $\begin{array}{c}\text { Percentag } \\
\text { es }\end{array}$ & & 92.0 & 8.0 & 0.0 & & & & & \\
\hline \multirow{2}{*}{5} & $\begin{array}{c}\text { Frequenci } \\
\text { es }\end{array}$ & \multirow{2}{*}{$\begin{array}{l}\text { Providing instructions in } \\
\text { simple textual, visual or } \\
\text { audio formats. }\end{array}$} & 18 & 7 & 0 & \multirow{2}{*}{2.72} & \multirow{2}{*}{0.46} & \multirow{2}{*}{$\begin{array}{c}89.8 \\
\%\end{array}$} & \multirow{2}{*}{ High } & \multirow{2}{*}{8} \\
\hline & $\begin{array}{c}\text { Percentag } \\
\text { es }\end{array}$ & & 72.0 & 28.0 & 0.0 & & & & & \\
\hline \multirow{2}{*}{6} & $\begin{array}{c}\text { Frequenci } \\
\text { es }\end{array}$ & $\begin{array}{l}\text { Taking into account } \\
\text { digital games pace in }\end{array}$ & 21 & 3 & 1 & & & & & \\
\hline & $\begin{array}{c}\text { Percentag } \\
\text { es }\end{array}$ & $\begin{array}{l}\text { tandem with intellectual } \\
\text { disabled children's } \\
\text { cognitive capacities. }\end{array}$ & 84.0 & 14.0 & 4.0 & 2.80 & 0.50 & $\%$ & High & 6 \\
\hline & $\begin{array}{c}\text { Frequenci } \\
\text { es }\end{array}$ & $\begin{array}{l}\text { Used symbols and fonts } \\
\text { must be familiar to }\end{array}$ & 23 & 1 & 1 & & & 95.0 & & \\
\hline & $\begin{array}{c}\text { Percentag } \\
\text { es }\end{array}$ & $\begin{array}{l}\text { intellectual disabled } \\
\text { children. }\end{array}$ & 92.0 & 4.0 & 4.0 & 2.00 & ד.ד & $\%$ & H. & $T$ \\
\hline 8 & Frequenci & Using colors, changing & 15 & 9 & 1 & 2.56 & 0.58 & 84.5 & High & 10 \\
\hline
\end{tabular}




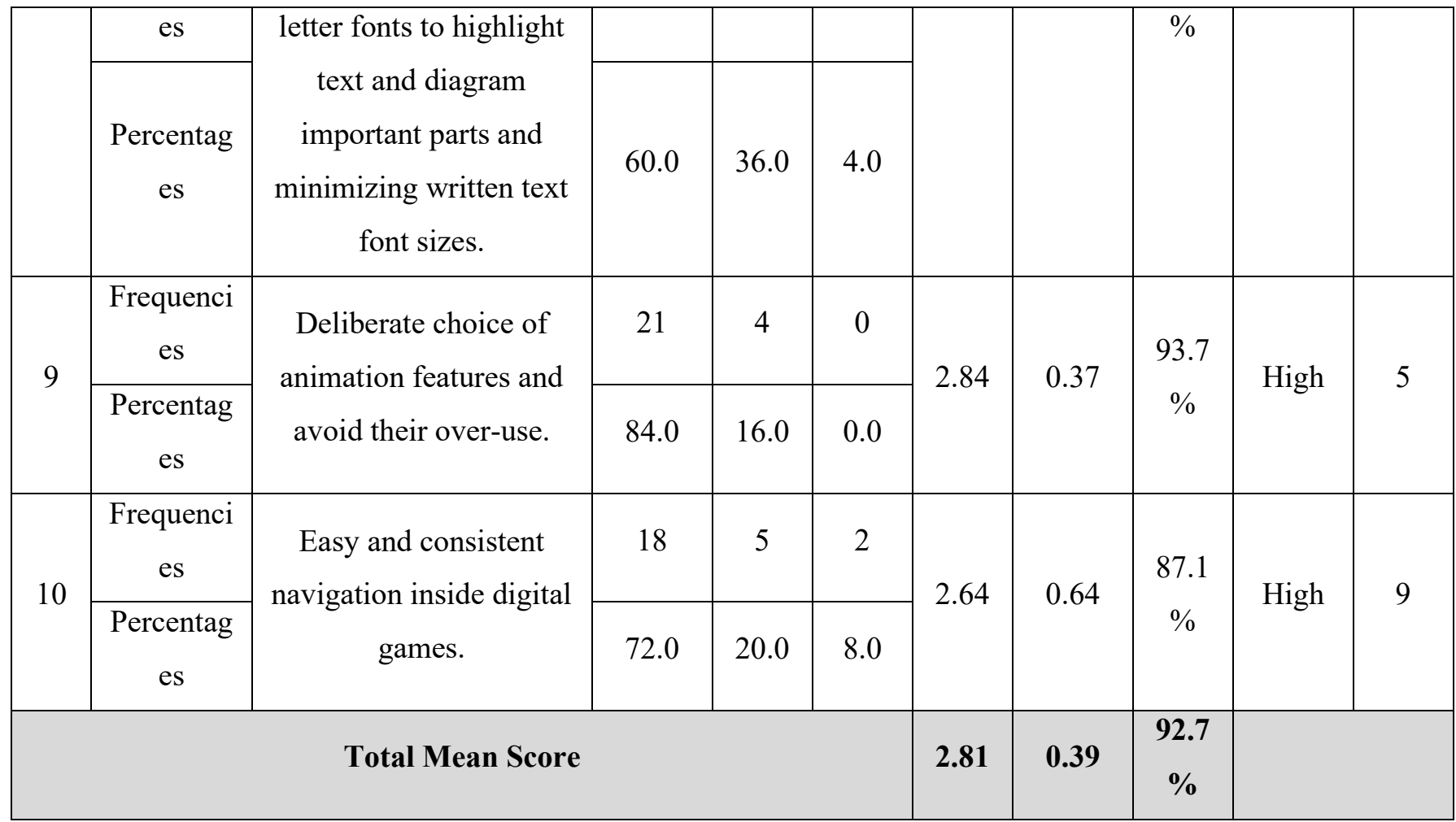

As Table (6) indicates, the questionnaire second dimension has a total mean score with a statistically significant value; thus emphasizing the fact that the instructional design requirements for using digital games-based learning at educable intellectual disabled children's classes have a high degree of importance.

\section{* Answering the Third Question:}

The third question states "What are the practical application requirements for using digital games-based learning at educable intellectual disabled children's classes?"

To answer such question, the researchers calculated the frequencies, percentages, mean scores and relative weights of the sample participants' responses to the questionnaire third dimension items that were then arranged in descending order in light of their ranks; thus concluding the following results:

Table (7):

Sample Participants' Responses for Identifying the Practical Application Requirements for Using Digital Games-Based Learning at Educable Intellectual Disabled Children's Classes $(N=25)$

\begin{tabular}{|c|c|c|c|c|c|c|}
\hline \multirow{2}{*}{$\mathbf{S} / \mathbf{N}$} & \multirow{2}{*}{$\begin{array}{c}\text { Frequencie } \\
\text { s }\end{array}$} & \multirow{2}{*}{ Items } & \multicolumn{3}{|c|}{ Response Degree } & $\mathbf{M}$ \\
\hline & & & Very & Impo & Not & an \\
\hline
\end{tabular}




\begin{tabular}{|c|c|c|c|c|c|c|c|c|c|c|}
\hline & $\begin{array}{c}\text { \& } \\
\text { Percentage } \\
\text { s }\end{array}$ & & $\begin{array}{c}\text { Import } \\
\text { ant }\end{array}$ & rtant & $\begin{array}{l}\text { Impo } \\
\text { rtant }\end{array}$ & $\begin{array}{c}\text { Sco } \\
\text { re }\end{array}$ & $\begin{array}{c}\text { Deviat } \\
\text { ion }\end{array}$ & $\begin{array}{c}\text { Weig } \\
\text { ht }\end{array}$ & $\begin{array}{c}\text { Degre } \\
\text { e }\end{array}$ & \\
\hline & Frequencies & \multirow[b]{2}{*}{$\begin{array}{c}\text { Availability of } \\
\text { logistical infrastructure } \\
\text { and facilities as well as } \\
\text { assistive technologies } \\
\text { for intellectual } \\
\text { disabled children. }\end{array}$} & 19 & 6 & 0 & \multirow[b]{2}{*}{$\begin{array}{c}2.7 \\
6\end{array}$} & \multirow[b]{2}{*}{0.00} & \multirow[b]{2}{*}{$\begin{array}{c}91.1 \\
\%\end{array}$} & \multirow[b]{2}{*}{ High } & \multirow[b]{2}{*}{5} \\
\hline 1 & Percentages & & 67.0 & 24.0 & 0.0 & & & & & \\
\hline \multirow[b]{2}{*}{2} & Frequencies & \multirow{2}{*}{$\begin{array}{l}\text { Providing trained } \\
\text { teachers capable of } \\
\text { using digital games in } \\
\text { teaching intellectual } \\
\text { disabled children. }\end{array}$} & 24 & 1 & 0 & \multirow[b]{2}{*}{$\begin{array}{l}29 . \\
96\end{array}$} & \multirow[b]{2}{*}{0.20} & \multirow[b]{2}{*}{$\begin{array}{c}97.7 \\
\%\end{array}$} & \multirow[b]{2}{*}{ High } & \multirow[b]{2}{*}{1} \\
\hline & Percentages & & 69.0 & 4.0 & 0.0 & & & & & \\
\hline \multirow[b]{2}{*}{3} & Frequencies & \multirow{2}{*}{$\begin{array}{l}\text { Reducing time periods } \\
\text { allocated for operating } \\
\text { and using digital } \\
\text { games. }\end{array}$} & 21 & 4 & 0 & \multirow[b]{2}{*}{$\begin{array}{c}2.8 \\
4\end{array}$} & \multirow[b]{2}{*}{0.37} & \multirow[b]{2}{*}{$\begin{array}{c}93.7 \\
\%\end{array}$} & \multirow[b]{2}{*}{ High } & \multirow[b]{2}{*}{3} \\
\hline & Percentages & & 84.0 & 4.0 & 0.0 & & & & & \\
\hline \multirow[b]{2}{*}{4} & Frequencies & \multirow{2}{*}{$\begin{array}{l}\text { Equipping intellectual } \\
\text { disabled children with } \\
\text { necessary technical } \\
\text { skills before using } \\
\text { digital games. }\end{array}$} & 18 & 6 & 1 & \multirow[b]{2}{*}{$\begin{array}{c}2.6 \\
8\end{array}$} & \multirow[b]{2}{*}{0.56} & \multirow[b]{2}{*}{$\begin{array}{c}88.4 \\
\%\end{array}$} & \multirow[b]{2}{*}{ High } & \multirow[b]{2}{*}{6} \\
\hline & Percentages & & 72.0 & 240. & 4.0 & & & & & \\
\hline \multirow[b]{2}{*}{5} & Frequencies & \multirow{2}{*}{$\begin{array}{l}\text { Digital games easy } \\
\text { operation by } \\
\text { intellectual disabled } \\
\text { children. }\end{array}$} & 23 & 2 & 0 & \multirow[b]{2}{*}{$\begin{array}{c}2.9 \\
2\end{array}$} & \multirow[b]{2}{*}{0.28} & \multirow[b]{2}{*}{$\begin{array}{c}96.4 \\
\%\end{array}$} & \multirow[b]{2}{*}{ High } & \multirow[b]{2}{*}{2} \\
\hline & Percentages & & 92.0 & 8.0 & 0.0 & & & & & \\
\hline \multirow{2}{*}{6} & Frequencies & Easy exit from digital & 20 & 5 & 0 & 2.8 & 0.41 & 92.4 & High & 4 \\
\hline & Percentages & games. & 80.0 & 20.0 & 0.0 & 0 & & $\%$ & & \\
\hline & Frequencies & Providing user & 12 & 11 & 2 & & & & & \\
\hline 7 & Percentages & $\begin{array}{l}\text { teachers to employ } \\
\text { digital games in } \\
\text { teaching intellectual }\end{array}$ & 48.0 & 44.0 & 8.0 & $\begin{array}{c}2.4 \\
0\end{array}$ & 0.65 & $\begin{array}{c}79.2 \\
\%\end{array}$ & High & 9 \\
\hline
\end{tabular}




\begin{tabular}{|c|c|c|c|c|c|c|c|c|c|c|}
\hline & & disabled children. & & & & & & & & \\
\hline \multirow[b]{2}{*}{8} & Frequencies & \multirow{2}{*}{$\begin{array}{l}\text { Digital games design } \\
\text { supports providing } \\
\text { social contexts suitable } \\
\text { for intellectual } \\
\text { disabled children's } \\
\text { learning. }\end{array}$} & 16 & 8 & 1 & \multirow[b]{2}{*}{$\begin{array}{c}2.6 \\
0\end{array}$} & \multirow[b]{2}{*}{0.58} & \multirow[b]{2}{*}{$\begin{array}{c}85.8 \\
\%\end{array}$} & \multirow[b]{2}{*}{ High } & \multirow[b]{2}{*}{7} \\
\hline & Percentages & & 64.0 & 32.0 & 4.0 & & & & & \\
\hline \multirow[b]{2}{*}{9} & Frequencies & \multirow{2}{*}{$\begin{array}{l}\text { Designing digital game } \\
\text { challenges that can be } \\
\text { overcome (i.e. neither } \\
\text { too simple nor } \\
\text { extremely complex). }\end{array}$} & 11 & 12 & 2 & \multirow[b]{2}{*}{$\begin{array}{c}2.3 \\
6\end{array}$} & \multirow[b]{2}{*}{0.64} & \multirow[b]{2}{*}{$\begin{array}{c}77.9 \\
\%\end{array}$} & \multirow[b]{2}{*}{ High } & \multirow[b]{2}{*}{10} \\
\hline & Percentages & & 44.0 & 48.0 & 8.0 & & & & & \\
\hline \multirow[b]{2}{*}{10} & Frequencies & \multirow[b]{2}{*}{$\begin{array}{l}\text { Allowing intellectual } \\
\text { disabled children to } \\
\text { cooperate together } \\
\text { while playing with } \\
\text { other real or virtual } \\
\text { partners to accomplish } \\
\text { required tasks. }\end{array}$} & 13 & 11 & 1 & \multirow[b]{2}{*}{$\begin{array}{c}2.4 \\
8\end{array}$} & \multirow[b]{2}{*}{0.48} & \multirow[b]{2}{*}{$\begin{array}{c}81.8 \\
\%\end{array}$} & \multirow[b]{2}{*}{ High } & \multirow[b]{2}{*}{8} \\
\hline & Percentages & & 52.0 & 44.0 & 4.0 & & & & & \\
\hline \multicolumn{6}{|c|}{ Total Mean Score } & $\begin{array}{c}2.6 \\
8\end{array}$ & 0.47 & $\begin{array}{c}\% 88 \\
.4\end{array}$ & & \\
\hline
\end{tabular}

As Table (7) summarizes, the questionnaire third dimension has a total mean score with a statistically significant value; thus emphasizing the fact that the practical application requirements for using digital games-based learning at educable intellectual disabled children's classes have a high degree of importance.

Furthermore, in order to identify the overall results and importance degree of sample participants' responses for identifying the requirements for designing and using digital games-based learning by educable intellectual disabled children, the researchers calculated the questionnaire total score in light of its dimension mean scores; thus concluding the following results:

\section{Table (8):}

Overall Results of Sample Participants' Responses for Identifying the Requirements for Designing and Using Digital Games-Based Learning by Educable Intellectual Disabled Children $(N=25)$ 


\begin{tabular}{|c|c|c|c|c|c|}
\hline $\begin{array}{c}\text { Questionnaire } \\
\text { Dimensions }\end{array}$ & $\begin{array}{c}\text { No. of } \\
\text { Items }\end{array}$ & $\begin{array}{c}\text { Mean } \\
\text { Score }\end{array}$ & $\begin{array}{c}\text { Relative } \\
\text { Weight }\end{array}$ & $\begin{array}{c}\text { Importance } \\
\text { Degree }\end{array}$ & Rank \\
\hline $\begin{array}{c}\text { First Dimension: } \\
\text { Educational Requirements }\end{array}$ & 18 & 2.70 & $89.1 \%$ & High & 2 \\
\hline $\begin{array}{c}\text { Second Dimension: } \\
\text { Instructional Design Requirements }\end{array}$ & 10 & 2.81 & $92.7 \%$ & High & 1 \\
\hline $\begin{array}{c}\text { Third Dimension: } \\
\text { Practical Application Requirements }\end{array}$ & 10 & 2.68 & $88.4 \%$ & High & 3 \\
\hline Requirements Total Score & $\mathbf{3 8}$ & $\mathbf{2 . 7 3}$ & $\mathbf{9 0 . 1 \%}$ & \multicolumn{2}{|c|}{ High } \\
\hline
\end{tabular}

As Table (8) shows, the questionnaire total mean score is 2.73 with a relative weight of $90.1 \%$. Overall, such values emphasize the fact that all the questionnaire educational, instructional design and practical application requirements for using digital games-based learning at educable intellectual disabled children's classes have a high degree of importance.

\section{8-Discussion:}

The study aimed to identify the requirements for designing and using digital games-based learning at educable intellectual disabled children's classes in Egypt. Following statistical analysis, the researchers concluded the following main results for their study, namely:

First, Table (5) indicates that based on examining the questionnaire item mean scores of its first dimension dealing with the educational requirements for using digital games with intellectual disabled children, we notice that they have high mean scores representing instructional design process initial stages that usually help to increase teachers' possible success in teaching those children using digital games. Also, they show the importance of immediate feedback for increasing such children's motivation to continue learning and their acquaintance with the desired goals as a very important requirement for promoting their motivation to learn the required skills step by step. Besides, the game ideas must be logically sequenced so as to enable intellectual disabled children to understand and deal with them quickly. In addition, simulation is so important for digital games simulating real problems facing those children that it helps them to effectively immerse into the games; thus increasing their motivation to move from one game level to another side by side with developing their ability to reach desired social satisfaction, e.g. acceptance and sense of belonging.

Notably, such result came in tandem with the previous results concluded by following studies in relevant educational literature, namely: Hasselbring \& Glaser (2000); Verenikina et al (2003); 
Kirriemuir \& McFarlane (2004); Fisch (2005); Bierre et al (2005); Kearney (2005); Baek (2008); Annetta et al (2009); Hovious \& Van Eck (2015).

Second, Table (6) shows that based on statistical analysis of the questionnaire second dimension results focusing on the instructional design requirements for using digital games-based learning with intellectual disabled children, we notice that they provide us with statistically significant values either for the questionnaire items, dimensions or total mean scores indicators. Such results may be attributed to the high importance degree of user interfaces. Indeed, when we deal with any digital game, it is necessary for users or children to interact and to adapt to game user interfaces before being able to carry out assigned orders or instructions. Notably, such user interfaces are the first tools encouraging children to positively interact with applied games. Besides, without accessibility potentials, verbal instructions and technical support in tandem with children's disability levels, such games become useless.

In addition, used graphics and diagrams must be familiar to intellectual disabled children for easy understanding and interpretation. It's noticeable that children's navigation processes between digital game components are not usually complex or sub-branched to suit their capabilities and attention span. Meanwhile, digital games delivered content targeting educable intellectual disabled children must focus on developing their life skills and behaviors as well as developing their ability to functionally change sizes and colors to highlight important parts of used texts and diagrams (that must be few in the digital games specifically designed for those children).

Notably, such result came in tandem with the previous results concluded by following studies in relevant educational literature, namely: Detheridge (1996); Brooks (1997); Hasselbring \& Glaser (2000); Christakis (2002); Bieere et al (2005); Saridaki et al (2009); and Hovious \& Van Eck (2015).

Third, as Table (7) concluded results concerning the practical application requirements for using digital games-based learning show, all proposed requirements have a high importance degree; thus emphasizing the top priority of training teachers on using technological innovations in general, particularly digital games, in maximizing their skills and making utmost use of such advanced tools in teaching intellectual disabled children. Undoubtedly, without providing training on using such games, it would be impossible to properly employ and benefit from all their various tools and advantages. In addition, accessibility requirements must be fulfilled in tandem with the inherent nature and characteristics of the targeted disability category whose children may become reluctant to use delivered digital games if they encounter any difficulties in their practical use.

In particular, the above-mentioned results emphasized that paying attention to digital games content and easy or difficult operation levels in tandem with the targeted disability category would ostensibly lead to making preparing their user manual unnecessary. However, designing digital game 
with higher complexity level would ultimately require teachers to rely on standardized user manuals guiding them to how properly employ and use such games with intellectual disabled children.

Notably, such result came in tandem with the previous results concluded by following studies in relevant educational literature, namely: Standen \& Low (1996); Brooks (1997); Hasselbring \& Glaser (2000); Kirriemuir \& McFarlene (2004); Sandford \& Williamson (2005); Bierre at al (2005); De Frietas (2006); Annetta et al (2009); and Hovious \& Van Eck (2015).

Fourth, Table (8) overall results concerning the requirements for designing and using digital games-based learning at educable intellectual disabled children's classes have high importance degree for the questionnaire all three dimensions. Notably, the instructional design requirements were ranked first as the most pivotal influencing factor of attracting intellectual disabled children to use digital games. Then, the educational requirements were second because they are, indeed, indispensable for those children's benefit from delivered digital games and accomplishment of their desired goals. Finally, the practical application requirements came third as their fulfillment supports the digital games successful use and ultimately result in realizing their educational goals in practice.

It's against such backdrop that the current study has already answered its three sub-questions and discussed their relevant results in detail.

\section{Suggestions and Recommendations:}

- Fulfilling the requirements for digital games use activities before its practical utilization in teaching educable intellectual disabled children;

- Making full use of digital games in developing intellectual disabled children's different life skills and concepts;

- Involving parents as well as intellectual disability school administrators in supporting the success of using digital games;

- Significance of taking into consideration the dominant developmental characteristics when preparing instructional design models for digital games used with educable intellectual disabled children as well as providing advanced training programs for teachers on how to produce and use digital games at those children's classes; and

- Designing user manuals and handbooks for teachers for assisting them in using and employing digital games at intellectual disabled children's. 


\section{References}

[1] American Association on Intellectual \& Developmental Disabilities (AAIDD). Frequently asked questions on intellectual disability and the AAIDD definition. Washington, DC.

(2008); retrieved from:https://www.aaidd.org/docs/default-source/sisdocs/aaiddfaqonid template.pdf?sfvrsn=9a63a874_2

[2] Saridaki M, Gouscos D, Meimaris. Digital games-based learning for students with intellectual disability. In P. Felicia (Ed.). Developments in Current Game-Based Learning Design and Deployment. (2009); $\quad$ Hershey, PA: IGI Global. 304-325.

[3] British Educational Communications \& Technology Agency (BECTA). Digital games in education; (2008). London; UK; The Author.

[4] American Psychiatric Association (APA) (1994). Diagnostic and statistical manual of mental disorders (4th ed.) (DSM-IV), Washington DC: American Psychiatric Association.

[5] Schalock, R. L., Luckasson, R. A., Shogren, K. A., Borthwick-Duffy, S., Bradley, V., Buntinx, W. H. E. . . Yeager, M. H. The renaming of mental retardation: Understanding the change to the term intellectual disability. Intellectual and Developmental Disabilities. (April 2007); 45 (2):116-124.

[6] Ke, F. A qualitative meta-analysis of computer games as learning tools. In R.E. Ferdig (Ed.), Handbook of research on effective electronic gaming ineducation. (2009); New York, NY; IGI Global; 1-32

[7] Becker, K. How are games educational? Learning theories embodied in games. Paper presented at the proceedings of the DiGRA $2^{\text {nd }}$ International conference on changing views; Worlds in Play, (2005b); Vancouver;Canada.

[8] Chen M.P., Wang L.C. The Effects of Type of Interactivity in Experiential Game-Based Learning. In: Chang M., Kuo R., Kinshuk, Chen GD., Hirose M. (eds) Learning by Playing. Game-based Education System Design and Development. Edutainment 2009. Lecture Notes in Computer Science, (5670). Springer, Berlin, Heidelberg. (2009); 273-282,.

[9] Gagné R., Brigg L, Wager W. Principles of instructional design ( $4^{\text {th }}$ ed.). Fort Worth, TX. (1992).Harcourt publishers.21-34

[10] Gardner H. Frames of Mind: The Theory of Multiple Intelligences. (1983).New York, NY: Basic Books. 77-315.

[11] Becker K. Games and learning styles. Paper presented at the proceedings of the special session on computer games for learning and teaching, at the IASTED International conference on education and education and Technology (2005a). Calgary-Canada. 
[12] Tsai, F. H., Yu, K. C., \& Hsiao, H. S. Exploring the factors influencing learning effectiveness in digital game-based learning. Journal of Educational Technology \& Society. (2012);, 15(3), 240-250.

[13] Kalantzis, K. Didactics of Special Educational Schools, for mentally retarded children. Karavias. Athens. (in Greek). (1985).

[14] Brooks R. Special educational needs and information technology. Effective strategies for mainstream schools. Berkshire, UK. National foundation for educational research. (1997).

[15] Rooms M. Information and communication technology and dyslexia. In J. Townend \& M. Turner (Eds.), dyslexia in practice. A Guide for teachers. New York, NY; plenum publishers. (2000); 263-272

[16] Christakis K. Educational approach of ahildren and young people with mild and severe learning difficulties. (2002). Athens, Greece: Atropos press.44-48.

[17] Raybourn, E. M., \& Waern, A. Social learning through gaming Association for Computing Machinery, Inc , One Astor Plaza, 1515 Broadway, New York. (2004): 1733-1734

[18] Lester J. Brigadoon, an Innovative online community for people dealing with Asperger's syndrome and autism. retrieved from: http:// braintalk.blogs.com/brigadoon/2005/01/about brigadoon.html

[19] Linehan C, Karman B, Lawson S, Chan G. Practical, appropriate, empirically validated guidelines for designing educational games. Paper presented at the proceedings of the annual conference on human factors in computing systems. New York-NY. (2011): 1979-1988

[20] Bredekamp S, Copple C. Developmentally appropriate practice in early childhood programs serving children from birth through age 8 . Washington, DC: National association for the education of young children. (2009).11-15

[21] Prensky M. Computer games and learning: digital game-based learning. In J. Reasons \& J. Goldstein (Eds.). Handbook of computer game studies. Cambridge, MA: MIT press. (2005): $97-122$

[22] Hasselbring, T. S., \& Glaser, C. H. Use of computer technology to help students with special needs. Children \& Computer Technology. (2000); 10 (2): 76-101.

[23] Briere K., Chetwynd J, Pierre E, Hinn M , Ludie S , Westin T. Game not over: accessibility issues in video games. Paper presented at the proceedings of the $3^{\text {rd }}$ International conference on universal access in Human-Computer Interaction, San Francisco-CA. (2005).

[24] Hovious, A. S., \& Van Eck, R.,N. Digital games or 21st-century learning: Teacher librarians' beliefs and practices. Teacher Librarian,. (2015, 06); 42 (5): 34-38. 
[25] Nolan, J., \& McBride, M. (2014). Beyond gamification: Reconceptualizing game-based learning in early childhood environments. Information, Communication \& Society. (2014). 17 (5): 594-608.

[26] Renkl, A., \& Atkinson, R. Interactive learning environments: Contemporary issues and trends. An introduction to the special issue. Educational Psychology Review. (2007); 19: 235 238.

[27] Ritterfeld, U., Shen, C., Wang, H., Nocera, L., \& Wong, W. L. Multimodality and interactivity: Connecting properties of serious games with educational outcomes. Cyberpsychology \& Behavior : The Impact of the Internet, Multimedia and Virtual Reality on Behavior and Society, (2009); 12(6), 691-697.

[28] Liao, C., Chen, Z., Cheng, H., Chen, F., \& Chan, T. My-mini-pet: A handheld pet-nurturing game to engage students in arithmetic practices. Journal of Computer Assisted Learning, (2011): 27(1), 76-89.

[29] Qin, H., Rau, P. P., \& Salvendy, G. Measuring player immersion in the computer game narrative. International Journal of Human-Computer Interaction, (2009); 25(2), 107-133.

[30] Blascovich J, Beilinson J. Infinite reality: Avatars, eternal Life, New Worlds, and the Dawn of the Virtual Revolution. New York, NY: HarperCollins. (2011).65-82.

[31] Tamborini, R., \& Skalski, P .The role of presence in the experience of electronic games. In P. Vorderer \& J. Bryant (Eds.), Playing video games: Motives, Responses and Consequences Hillsdale, NJ: Lawrence Erlbaum Associates. (2006): 225-240

[32] Vera L, Herrera G, Vived E. Virtual reality school for children with learning difficulties. Paper presented at the proceedings of ACM SIGCHI International conference on advances in computer entertainment technology (pp.). New York. NY: ACM press. (2005): 338-341

[33] Padgett, L. S., Strickland, D., \& Coles, C. D. Case study: Using a virtual reality computer game to teach fire safety skills to children diagnosed with fetal alcohol syndrome. Journal of Pediatric Psychology, (2006);31(1), 65-70.

[34] Marco, J., Cerezo, E., \& Baldassarri, S. Bringing tabletop technology to all: Evaluating a tangible farm game with kindergarten and special needs children. Personal and Ubiquitous Computing, (2013); 17(8), 1577-1591.

[35] Chuang, T., Lee, I., \& Chen, W. Use of digital console game for children with attention deficit hyperactivity disorder. US-China Education Review(2010);, 7(11), 99-105.

[36] Williams, C., Wright, B., Callaghan, G., \& Coughlan, B. Do children with autism learn to read more readily by computer assisted instruction or traditional book methods?: A pilot study. Autism: The International Journal of Research and Practice, (2002); 6(1), 71-91. 
[37] Griffiths, M.D.The educational benefits of videogames. Journal of Education and Health. (2002); 20 (3): 47-63.

[38] Walpole R. Introduction to Statistics (2nd ed). Macmillan Publishing Co, Inc. New York. (1998) :148-149.

[39] Verenikina I, Harris, P, Lysaght P. Child's play: Computer games, theories of play and children's development. Paper presented at the proceedings of the international federation for information processing working group on young children and Learning Technologies. Sydney-Australia. (2003): 99-106

[40] Kirriemuir J, McFarlane. A. Literature Review in games and learning. Bristol, UK: NESTA Futrelab (2004).

[41] Fisch, S. M. Making educational computer games 'educational' Association for Computing Machinery, Inc , One Astor Plaza, 1515 Broadway, New York,. (2005):55-61.

[42] Kearney, R. Playing in the sandbox: developing games for children with disabilities. Paper presented at the proceedings of DiGRA 2nd international conference on changing viewsworlds in play, Vancouver-Canada; (2005).

[43] Baek, Y. K. What hinders teachers in using computer and video games in the classroom? exploring factors inhibiting the uptake of computer and video games. Cyberpsychology \& Behavior : The Impact of the Internet, Multimedia and Virtual Reality on Behavior and Society, (2008); 11 (6): 667-671.

[44] Annetta, L. A., Minogue, J., Holmes, S. Y., \& Cheng, M. Investigating the impact of video games on high school students' engagement and learning about genetics. Computers \& Education, (2009); 53 (1): 74-85.

[45] Detheridge, T. Information technology. In B. Carpenter, R. Ashdow \& K. Bovair (Eds.), Enabling Access: Effective Teaching and Learning for Pupils with Learning Difficulties. London, UK: David Fulton; (1996): 14-36

[46] Stenden P.J , Low H. L. Do virtual environments promote self-directed activity? A study of students with severe learning difficulties learning ${ }^{\text {Makaton }}$ sign language. In P.M. Sharkey (Ed.), Proceedings of the 1st European conference on disability, Virtual Reality and Associated Technologies. Maidenhead-UK. (1996): 123-127.

[47] Sandford R., Williamson B. Games and Learning. Bristol, UK: NESTA Futrelab.

[48] de Freitas, S.,I. Using games and simulations for supporting learning. Learning, Media and Technology, (2006); 31 (4): 343-358. 